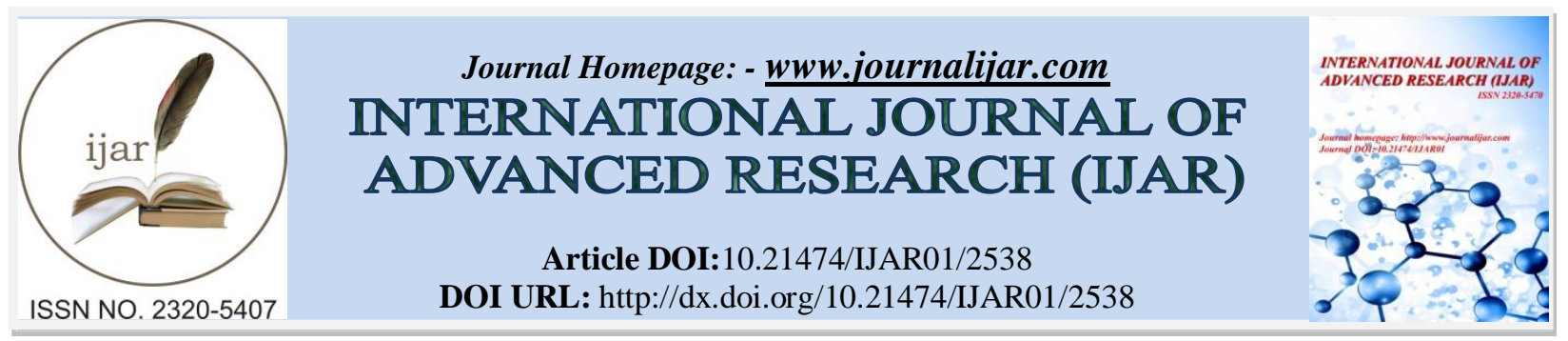

RESEARCH ARTICLE

\title{
EVALUATION OF PHYSICOCHEMICAL CHARACTERISTICS OF GOMTI RIVER WATER AT UTTAR PRADESH, INDIA.
}

\author{
Hafizurrahman ${ }^{1 *}$, Abrar Ahmad ${ }^{2}$, MohdMabood Khan ${ }^{3}$ and ZulfiqarAli ${ }^{1}$. \\ 1. Department of Chemistry, Integral University, Kursi Road, Lucknow, India. \\ 2. Environmental Biotechnology Division, CSIR-IITR, MG Road, Lucknow, India. \\ 3. Department of Pathology, King George Medical University, Lucknow, India.
}

\section{Manuscript Info}

\section{Manuscript History}

Received: 25 October 2016

Final Accepted: 23 November 2016

Published: December 2016

Key words:-

Physicochemical parameters, River

Gomti, DO, COD, BOD

\section{Abstract}

The aim of the study is to find out the water quality of the Gomti River of Uttar Pradesh. River Gomti is an important River of Uttar Pradesh, originate from the FulhaarJheel present in Pilibhit region in Uttar Pradesh. The River goes for a distance of about $900 \mathrm{~km}$, passing through Uttar Pradesh finally to join River Ganges in Ghazipur in the area of Saidpur. Different cities that are located along the banks of the River Gomti are Sultanpur, Lucknow, Jaunpur and these are the main cities that are prominent in the region, out of the total 15 cities in the catchment land. A total 10 parameters namely Temperature, $\mathrm{pH}$, Total dissolved solids (TDS), Total hardness, Alkalinity, free $\mathrm{CO}_{2}$, Dissolved oxygen (DO), Biological oxygen demand (BOD), Chemical oxygen demand (COD) and Chlorides were analyzed and their seasonal variation is discussed to obtain the impact of effluents on water quality. The observed values of different physicochemical parameters were compared with standard values recommend by World Health Organization (WHO) and Bureau of Indian Standard (BIS).From the result it was found that the most of the parameters of Gomti River water are within the permissible limit of WHO and BIS but some parameters like $\mathrm{pH}, \mathrm{BOD}$ and $\mathrm{DO}$ were found higher than the permissible limit of $\mathrm{WHO}$ and BIS.

Copy Right, IJAR, 2016,. All rights reserved.

\section{Introduction:-}

Gomti River is one of the important tributaries of Ganga River which originates from a lake FulharJheel near Mainkot in Madhotanda, Uttar Pradesh and finally to join River Ganges in Gazipur. Four cities, Lucknow, Barabanki, Sultanpur and Jaunpur, are situated on the banks of this River. Water is absolutely essential for survival of human beings, animals, plants and other living beings because without water no life can exist (Patel, et al., 2015). Water pollution is a major global problem. Due to discharge of industrial effluents, domestic and sewage water, agricultural wastes and decaying materials of human, animals and plants polluted Indian Rivers day by day (Asthana, et al., 1997). It has been reported that water pollution leading worldwide cause of deaths and diseases and accounts for the deaths of 14,000 people daily (West, 2006). The main source of water pollution specially for Rivers flowing within the city are drains, which carry industrial effluents, domestic waste, sewage and medicinal waste causing water pollution (Srivastava, et al., 2011). The geochemical, geomorphological, climatic pollution nature of fresh water was characterized by the physicochemical parameter of water body (Chaurasia and Pandey, 2007). To 
ensure that the water is palatable and safe for drinking it is necessary to comply with physical, chemical and microbiological standards (Tebutt, 1983). According to the WHO reports approximately $36 \%$ of urban and 65\% of rural Indian were without access to safe drinking water (Akoto and Adiyiah, 2007). Keeping in view of the above facts the present work was focused to analyze physicochemical parameter of Gomti River water in Lucknow, Barabanki, Sultanpur and Jaunpur district affected by domestic wastes, agricultural wastes and sewage water which deteriorate the quality of water.

\section{Materials and Methods:- \\ Study Area:-}

Gomati River, also called Gumti, tributary of the Ganges (Ganga) River, central Uttar Pradesh state , Northern India. The River goes for a distance of about $900 \mathrm{~km}$, passing through Uttar Pradesh finally to join River Ganges in Ghazipur.Different cities that are located along the banks of the River Gomti are Sultanpur, Lucknow, Jaunpur and Lakhimpur Kheri, Barabanki and these are the main cities that are prominent in the region, out of the total 15 cities in the catchment land. The Gomti River catchment area is of about $25,800 \mathrm{~km} 2$. The nine-sampling site were selected for quantitative analysis of the physicochemical parameter in water column of the Gomti River. The selected sites are,Site1.Neemsar, Lucknow: About $100 \mathrm{~km}$ upstream of Lucknow.

Site2.Gaughat, Lucknow: Upstream of the Lucknow city near the water supply in take point from River.

Site3.Mohan Meakins, Lucknow: Downstream of the Mohan Meakins distilleryin the central city. Between Gaughat and Mohan Meakins locations, there are several outfalls/drains discharging into the River directly.

Site4. Pipraghat, Lucknow: In the cantonment area, downstream of Lucknow.

Site5.Barabanki, Downstream of Lucknow, Reith River, a tributary of Gomti River bringing wastewater/effluents from the Barabanki town (left) and Luni River from the right side joins the main River channel upstream of this location.

Site6. Gola Ghat, Sultanpur: About $10 \mathrm{~km}$ upstream of the Sultanpur town.

Site7. AamGhat, Sultanpur: Downstream of the Sultanpur town.

Site8.Hanuman Ghat, Jaunpur: About $10 \mathrm{~km}$ upstream of the Jaunpur city.

Site9. MiyanpurGhat, Jaunpur: About $3 \mathrm{~km}$ downstream of the Jaunpur.

\section{Collection of water sample:-}

In the present study, seasonal variations in physical and chemical parameters of Gomti River were studied. The sampling was done on winter season December 2015, summer season May 2016 and rainy season August 2016. The sample was collected from below the water in plastic bottles of $2 \mathrm{~L}$ capacity and stored for further analysis. The samples were analyzed for 10 different physicochemical parameters namely Temperature, $\mathrm{pH}$, Total dissolved solids (TDS), Total Hardness(TH), Alkalinity, Free $\mathrm{CO}_{2}$, Biological oxygen demand(BOD), Chemical oxygen demand (COD), Dissolved oxygen (DO) and chlorides.

\section{Physicochemical analysis:-}

The parameters like Temperature, $\mathrm{pH}$, TDS, Alkalinity, Total hardness, Free $\mathrm{CO}_{2}, \mathrm{BOD}, \mathrm{COD}, \mathrm{DO}$ and Chlorides were analyzed by using APHA, (1999) standard procedures.Total dissolved solid (TDS) was determined gravimetrically by evaporating a known amount of volume. $\mathrm{pH}$ was determined by digital $\mathrm{pH}$ meter. Temperature was measured by thermometer. Dissolved oxygen (DO) was measured by Azide modification titrimetric method. Chemical oxygen demand (COD) was determined by Open reflux methods. Biological oxygen demand (BOD) was determined by 5 days BOD test. Hardness of water was determined by EDTA titrimetric method. Chloride was analyzed by Argentometric titrimetric method. Free $\mathrm{CO}_{2}$ was determined by titrimetric method using phenolphthalein as an indicator at $\mathrm{pH}$ 8.3. Alkalinity was also determined by titrimetric method. The results obtained by different tests carried out on physicochemical properties of River water samples comprises with the World Health Organization (WHO, 2008), Bureau of Indian Standard (BIS, 2004) specified for drinking water.

\section{Results and Discussion:-}

In the present study total of 10 physicochemical parameters were analyzed namely Temperature, $\mathrm{pH}$, Alkalinity, TDS, BOD, COD, DO, Free $\mathrm{CO}_{2}$, Total hardness and Chlorides. The physicochemical properties of River Gomti were recorded in different season and at different sites as listed in Table 1and Table 2. 


\title{
Temperature
}

In winter season the highest value of $21.7 C^{\circ}$ temperature was found at Barabankiand lowestvalue of temperature 19.3 $\mathrm{C}^{\circ}$ was found at Golaghat. In summer season the highest value of temperature $33.8 \mathrm{C}^{\circ}$ was at Gaughat and lowest value temperature $30.6 \mathrm{C}^{\circ}$ was at Barabanki. In rainy season the highest value was $28.9 \mathrm{C}^{\circ}$ at Hanuman ghat and lowest value $23.5 \mathrm{C}^{\circ}$ was found at Golaghat. Similar observation have also reported by other workers in Indian Rivers, especially in Ganga (Kannan, 2000), in Gomti River (Arti Saxena, 2016) and Purna River, Maharastra(Meitei, et al.,2004). The variation in temperature is mainly related with the atmospheric temperature and weather condition (Adebowale, et al., 2008).

pH:-

In winter season the highest value of $\mathrm{pH} 8.56$ was at Pipraghat and lowest value 7.25 at Golaghat. In summer season the highest value 8.58 was at Pipraghat and lowest value was 7.23 at Miyanpurghat. In rainy season the highest value was 28.9 at Hanuman ghat and lowest value 23.5 at Golaghat. The value of $\mathrm{pH}$ expresses about the intensity of acidity and alkalinity of an aquatic environment (Kamal, et al., 2007). Bhagat, et al., 2013 has reported $\mathrm{pH}$ value within the range of 9.2-11.7 in Sutlej River Punjab and Purushottam, et al., 2016 reported within the range of 7.8-8.6 in Gomti River.

\section{Total dissolved solids (TDS):-}

Total dissolved solids are the amount of solid materials dissolved in water including salts, some organic materials and a wide range of other things from nutrient to other toxic materials.

In winter season the highest value $650.5 \mathrm{mg} / \mathrm{l}$ was at Hanuman ghat and lowest value $357 \mathrm{mg} / \mathrm{l}$ was at Neemsar. In summer season the highest value $667.5 \mathrm{mg} / \mathrm{l}$ was at Hanuman ghat and lowest value $455 \mathrm{mg} / \mathrm{l}$ was at Neemsar. In rainy season the highest value $498 \mathrm{mg} / \mathrm{l}$ was found at Pipraghat and lowest value $347 \mathrm{mg} / \mathrm{l}$ was at Neemsar.

\begin{abstract}
Alkalinity:-
Alkalinity of water is the capacity to neutralize strong acids and forms carbonate, bicarbonate,hydroxide content by the dissolution of $\mathrm{CO}_{2}$ in water. In winter season the highest value $234 \mathrm{mg} / \mathrm{lwasat}$ Neemsar and lowest $133 \mathrm{mg} / \mathrm{l}$ at Pipraghat. In summer season the highest value $232 \mathrm{mg} / \mathrm{l}$ at Neemsar and lowest value $129 \mathrm{mg} / \mathrm{l}$ at Pipraghat. In rainy season the highest value $246 \mathrm{mg} / \mathrm{l}$ was at Aamghat and lowest value $198 \mathrm{mg} / \mathrm{l}$ was at Mohanmekin. Similar results also observed by (Tabrez, et al., 2010) in Gomti River water.
\end{abstract}

\section{Total hardness (TH):-}

In the winter season the highest value $230 \mathrm{mg} / \mathrm{l}$ was at Aamghat and lowest value $154 \mathrm{mg} / \mathrm{l}$ was at Neemsar. In summer season the highest value $242 \mathrm{mg} / \mathrm{l}$ was found atMohanmekinand lowest value $198 \mathrm{mg} / \mathrm{l}$ at Pipraghat. In rainy season the highest value $212 \mathrm{mg} / \mathrm{l}$ was at Aamghat and lowest value $176 \mathrm{mg} / \mathrm{l}$ was at Mohanmekin. The hardness of natural waters depends mainly on the presence of dissolved calcium and magnesium salts (Ikomi and Emuh, 2000) and permanent hardness is mainly caused by chlorides and sulphates present in water (Roy, et al., 2002).The higher value of total hardness at different sites may be due to use of soaps and detergents by washer men and also discharge of the domestic wastes through drains. Total hardness has no adverse health effects except for imparting taste (WHO, 1996).

\section{Free $\mathrm{CO}_{2}$ :-}

In the winter season the highest value was $62.3 \mathrm{mg} / \mathrm{l}$ and lowest value $38.6 \mathrm{mg} / \mathrm{l}$ was at Neemsar. In the summer season the highest value $68.5 \mathrm{mg} / \mathrm{l}$ and lowest value $43.6 \mathrm{mg} / \mathrm{l}$ was at Neemsar. In the rainy season the highest value was $58.2 \mathrm{mg} / \mathrm{l}$ at Mohanmekin and the lowest value was $46.2 \mathrm{mg} / \mathrm{l}$ at Gaughat.Relatively higher values of free $\mathrm{CO}_{2}$ were observed during rainy season because in summer due to high temperature the respiratory activities of aquatic organisms accelerated by process of decay of organic matter, producing large amount of $\mathrm{CO}_{2}$ in the water (Pramod, et al.,2014). Similar results were observed by (Preetysingh, 2014) in Gomti River and (Meitei, et al., 2004) in Purna River.

\section{Biological oxygen demand (BOD):-}

In the winter season the highest value $6.4 \mathrm{mg} / \mathrm{l}$ was at Mohanmekin and lowest value $3.1 \mathrm{mg} / \mathrm{l}$ was at Golaghat. In the summer season the highest value $6.2 \mathrm{mg} / \mathrm{l}$ was at Mohanmekin and lowest value $3.8 \mathrm{mg} / \mathrm{l}$ was at Neemsar. In the rainy season the highest value $6.7 \mathrm{mg} / \mathrm{l}$ was at Mohanmekin and lowest value $2.8 \mathrm{mg} / \mathrm{l}$ was at Aamghat.Due to biodegradation of organic materials Biological oxygen demand increases and exerts oxygen tension in a water body 
(Abida and Harikrishna, 2008). BOD has been used to detect the amount of organic materials in water which supports the growth of microorganism (Goel, 2006). In the present study, the average value found was $4.6 \mathrm{mg} / \mathrm{l}$ is higher than the value obtained by the in Yamuna River (Khaiwal, et al., 2003) and in Ganga River (Khanna, et al.,2007) correspondingly.

\section{Chemical oxygen demand (COD):-}

In the winter season the highest value $21.5 \mathrm{mg} / \mathrm{l}$ was at Hanuman ghat and lowest value $13.6 \mathrm{mg} / \mathrm{l}$ was at Barabanki. In the summer season the highest value $21.8 \mathrm{mg} / \mathrm{l}$ was at Mohanmekin and lowest value $12.5 \mathrm{mg} / \mathrm{l}$ was at Golaghat. In the rainy season the highest value $22.4 \mathrm{mg} / \mathrm{l}$ at Mohanmekin and lowest value $12.8 \mathrm{mg} / \mathrm{l}$ at Neemsar. Low levels of COD indicate about comparatively less pollution load and high level of COD due to performance of worship rituals and abundance anthropogenic activities. Semwal and Akolkar, 2006 reported COD range between 11.018.3mg/lin Ganga River. Singh, et al., 2013 reported COD range 37.6-60.8 mg/l in Gomti River and Zeb, et al., 2011 reported COD range between 20.7- 28.2mg/l in Siran River Pakistan.

\section{Dissolve Oxygen (DO):-}

In the winter season the highest value $12.4 \mathrm{mg} / \mathrm{l}$ was at Barabanki and lowest value $7.8 \mathrm{mg} / \mathrm{l}$ was at Gaughat. In the summer season the highest value $11.9 \mathrm{mg} / \mathrm{l}$ was at Barabanki and lowest value $7.8 \mathrm{mg} / \mathrm{l}$ was at Hanuman ghat. In the rainy season the highest value $13.5 \mathrm{mg} / \mathrm{l}$ was at Neemsar and lowest value $7.6 \mathrm{mg} / \mathrm{l}$ was at Hanuman ghat. The deficiency of the oxygen in the water is favorable condition for bacteria and other pathogens, which are anaerobic and injurious to human health Radha,et al., 2007.Dissolved oxygen concentration is a most important Indicator of water pollution (Basavaraddi, et al., 2012). Similar observation also found by (Dhananjay, et al., 2013) in Gomti River water, in the Ganga River water values ranged between 9.50-11.0 mg/lit Bhutani, et al.,2014).

\section{Chlorides:-}

In the winter season the highest value $26 \mathrm{mg} / \mathrm{l}$ was at Gaughat and lowest value $16.5 \mathrm{mg} / \mathrm{l}$ was atGolaghat. In the summer season the highest value $31.6 \mathrm{mg} / \mathrm{l}$ was at Aamghat and lowest value $19.4 \mathrm{mg} / \mathrm{l}$ was at Neemsar. In the rainy season the highest value $24.3 \mathrm{mg} / \mathrm{l}$ was at Golaghat and lowest value $18.9 \mathrm{mg} / \mathrm{l}$ was at Neemsar. The chloride concentration indicates about the pollution caused by sewage. Higher chlorides in water are subjected to laxative effects in people (Dahiya, et al., 1999). The value of Chloride increases with the increasing of eutrophication (Mahananda, et al., 2010). Chlorides and sulphates produce permanent hardness in water (Roy, et al., 2002). 
Table1:-Physicochemical data of Gomti River in Winter, Summer, Rainy season at different site.

\begin{tabular}{|c|c|c|c|c|c|c|c|c|c|c|}
\hline Sites & Temp & pH & Alkalinity & TDS & Free $\mathrm{CO}_{2}$ & BOD & COD & DO & TH & Chloride \\
\hline \multicolumn{11}{|c|}{ December 2015 (Winter season) } \\
\hline 1 & 21.3 & 7.34 & 234 & 357 & 38.6 & 3.8 & 14.4 & 11.4 & 154 & 17.2 \\
\hline 2 & 22 & 7.26 & 215 & 398 & 44.3 & 4.2 & 15.8 & 10.2 & 176 & 16.5 \\
\hline 3 & 20.2 & 8.34 & 140 & 425 & 53.8 & 4.8 & 20.2 & 9.1 & 198 & 25.2 \\
\hline 4 & 19.5 & 8.56 & 133 & 620 & 50.2 & 6.4 & 19.6 & 10.6 & 166 & 18.3 \\
\hline 5 & 21.7 & 7.45 & 188 & 572.5 & 51.6 & 3.1 & 13.6 & 12.4 & 186 & 22.6 \\
\hline 6 & 19.3 & 7.25 & 167 & 438 & 58.2 & 3.6 & 15.3 & 7.8 & 220 & 26.0 \\
\hline 7 & 21.6 & 8.22 & 144 & 455 & 55.6 & 4.2 & 17.0 & 8.2 & 230 & 24.6 \\
\hline 8 & 20.0 & 7.92 & 198 & 650.5 & 62.3 & 4.4 & 21.5 & 8.5 & 213 & 22.2 \\
\hline 9 & 19.7 & 7.50 & 205 & 548 & 52.4 & 4.0 & 18.7 & 8.7 & 198 & 21.8 \\
\hline Average value & 20.56 & 7.76 & 180.44 & 462.66 & 51.88 & 4.6 & 17.31 & 9.65 & 193.44 & 21.6 \\
\hline \multicolumn{11}{|c|}{ May 2016 (Summer season) } \\
\hline 1 & 33.8 & 7.62 & 232 & 455 & 43.6 & 3.8 & 16.3 & 11.7 & 199 & 19.4 \\
\hline 2 & 33 & 7.85 & 212 & 468 & 48.3 & 4.6 & 15.4 & 11.1 & 216 & 20.8 \\
\hline 3 & 31.2 & 8.48 & 156 & 558 & 68.5 & 6.2 & 21.8 & 9.8 & 242 & 23.3 \\
\hline 4 & 32 & 8.58 & 129 & 650.5 & 57.9 & 5.5 & 17.5 & 11.3 & 198 & 20.9 \\
\hline 5 & 30.6 & 7.92 & 168 & 543 & 54.5 & 4.9 & 14.6 & 11.9 & 215 & 24.2 \\
\hline 6 & 32.8 & 7.56 & 220 & 486 & 60.3 & 3.9 & 12.5 & 10.2 & 237 & 29.3 \\
\hline 7 & 31.0 & 8.20 & 214 & 526 & 52.7 & 4.9 & 16.2 & 9.2 & 220 & 31.6 \\
\hline 8 & 33.3 & 7.90 & 198 & 667.5 & 62.1 & 4.5 & 20.7 & 7.8 & 225 & 26.9 \\
\hline 9 & 31.4 & 7.23 & 167 & 520 & 51.8 & 3.8 & 16.3 & 8.2 & 217 & 25.7 \\
\hline Average value & 28.56 & 7.92 & 188.44 & 541.55 & 55.52 & 4.6 & 16.81 & 10.13 & 218.77 & 24.67 \\
\hline \multicolumn{11}{|c|}{ August 2016 (Rainy Season) } \\
\hline 1 & 27.6 & 7.56 & 234 & 347 & 48.4 & 4.6 & 12.8 & 13.5 & 201 & 18.9 \\
\hline 2 & 26.0 & 7.24 & 220 & 358 & 46.2 & 4.1 & 13.6 & 12.3 & 197 & 19.3 \\
\hline 3 & 27.2 & 8.12 & 198 & 420 & 55.5 & 6.7 & 18.3 & 10.2 & 188 & 22.6 \\
\hline 4 & 25.6 & 7.88 & 216 & 498 & 58.2 & 5.9 & 22.4 & 11.4 & 176 & 21.2 \\
\hline 5 & 26.1 & 7.98 & 212 & 350 & 53.3 & 5.3 & 19.5 & 11.9 & 190 & 23.5 \\
\hline 6 & 23.5 & 7.81 & 235 & 415 & 48.9 & 2.8 & 21.2 & 9.9 & 195 & 24.3 \\
\hline 7 & 24.6 & 7.70 & 246 & 463 & 50.0 & 3.5 & 20.0 & 10.5 & 212 & 21.5 \\
\hline 8 & 28.9 & 7.88 & 233 & 388 & 55.2 & 3.6 & 18.9 & 7.6 & 187 & 22.8 \\
\hline 9 & 26.2 & 8.36 & 220 & 423 & 51.0 & 4.2 & 20.5 & 8.5 & 192 & 20.1 \\
\hline Average value & 26.18 & 7.83 & 223.77 & 406.88 & 51.85 & 4.52 & 18.57 & 10.66 & 214.44 & 21.57 \\
\hline
\end{tabular}

Table 2:-Comparative estimation of experimental values with WHO and BIS standards.

\begin{tabular}{|c|c|c|c|c|}
\hline S. No. & Parameters & Units & $\begin{array}{cc}\text { Standard } \\
\text { permissible limit) }\end{array}$ & $\begin{array}{l}\text { Experimental values } \\
\text { (Range) }\end{array}$ \\
\hline 1 & Temperature & $\mathrm{C}^{0}$ & ---- & $19.3-33.8$ \\
\hline 2 & $\mathrm{pH}$ & - & $6.5-8.5 \quad$ (BIS) & $7.23-8.58$ \\
\hline 3 & TDS & $\mathrm{mg} / \mathrm{l}$ & $(\mathrm{WHO})$ & $347-667.5$ \\
\hline 4 & BOD & $\mathrm{mg} / \mathrm{l}$ & (WHO) & $2.8-6.7$ \\
\hline 5 & COD & $\mathrm{mg} / \mathrm{l}$ & (WHO) & $12.5-22.4$ \\
\hline 6 & DO & $\mathrm{mg} / \mathrm{l}$ & (BIS) & $7.6-13.5$ \\
\hline 7 & Free $\mathrm{CO}_{2}$ & $\mathrm{mg} / \mathrm{l}$ & -- & $38.6-68.5$ \\
\hline 8 & Alkalinity & $\mathrm{mg} / \mathrm{l}$ & (BIS) & $129-246$ \\
\hline 9 & Total hardness & $\mathrm{mg} / \mathrm{l}$ & (WHO) & $154-242$ \\
\hline 10 & Chlorides & $\mathrm{mg} / \mathrm{l}$ & (WHO) & $17.2-31.6$ \\
\hline
\end{tabular}




\section{Conclusion}

Physicochemical analysis was performed on Gomti River water samples collected from various district in Uttar Pradesh, India. The results obtained in this study provide the characteristics of water, most of all parameters are within permissible limits except $\mathrm{pH}, \mathrm{BOD}$ and DO. Thus the present study revealed that the Gomti River was highly polluted and the water quality is not now in safe limit for human, flora and fauna. Therefore, to maintain, and improve the of quality water it is necessary to provide awareness in people for cleanness of River and also should be continuous monitoring of pollution level is necessary and immediate action is required for its better management.

\section{Acknowledgment:-}

The authors are thankful to Integral University, Lucknow for providing necessary facilities to carry out this study.

\section{References:-}

1. APHA, (1999): Standard methods for examination of water and waste water. American Public Health Associations, New York, P.709.

2. Asthana, R.K., Singh, K.N., and Murtaza, S.I., (1997), Deterioration of physicochemical and biological characters of lotic water affected by urban wastes. U. Scientist Phy. Sci. 9(1):101-104.

3. Akoto, O., and Adiyiah, J., (2007), Chemical analysis of drinking water from some communities in the BrongAhafo region, International Journal of Environmental Science and Technology, 4(2), 211-214.

4. Abida, B., and Harikrishna, (2008), Study on the Quality of Water in Some Streams of Cauvery River. Journal of Chemistry, 5(2): 377-384.

5. Arti Saxena (2016),Study of Water Quality of River Gomti at Lucknow Uttar Pradesh, International Interdisciplinary Research Journal, Volume-VI, ISSN 2249-9598.

6. Bureau of Indian Standards (2004), Indian Standards (IS: 10500) Drinking Water Specification: New Delhi.

7. Bhagat, S., Chauhan and Sagar, S.K., (2013), Impact of pollutants on the water quality of River Sutlej in Nangal area of Punjab, India, Biological forum, 5(1)113-123.

8. Basavaraddi, B.S., Kousar, H., and Puttaiah, E.T., (2012), Dissolved Oxygen Concentration a Remarkable Indicator of Ground Water Pollution, Bull. Env. Phar and Lif.1, 3: 48 - 54.

9. Bhutani, R., Khanna, D.R., Kulkarni DipaliBhaskar and RuhelaMukesh, (2014), Assessment of Ganga River ecosystem at Haridwar, Uttarakhand, India with reference to water quality indices. Appl waterSci (6):14-20.

10. Chaurasia, M., and Pandey, G.C., (2007), Study of physicochemical characteristics some water ponds of Ayodhya, Faizabad, Journal of environmental pollution, 27(1), 1019-1023.

11. Dahiya, S., Kaur, A., (1999), Physico chemical characteristics of underground water in rural areas of Tosham subdivisions, Bhiwani district, Haryana, Journal of Environment Pollution 6 (4), 281.

12. Goel, P. K., (2006), Water pollution: causes, effects and control, New Age International.

13. Ikomi, R. B., and Emuh, C. T., (2000), The Status of the physicochemical Hydrology of Upper Warri River Nigeria. Journal of Science and Environment, 2: 75-86.

14. Khanna, D.R., Sarkar, P., Gautam, A., Bhutiani, R., (2007), Fish scales as bio-indicator of water quality of River Ganga. Environ. Monit. Assess 134:153-160.

15. Khaiwal, R., Ameena, M., Rani, M., Anubha, K., (2003), Seasonal variations in physicochemical characteristics of River Yamuna in Haryana and its ecological best designated use, J. Environ. Monit. 5:419-426.

16. Kamal, D., A.N. Khan, A.N., M.A. Rahman, M.A. and F. Ahmad, F., (2007), Study on the Physicochemical properties of water of Mouri River, Khulna, Bangladesh, Pakistan journal of Biological Sciences 10(5):710-717.

17. Kannan, K.G., (2000), Physicochemical and ecological study of River Ganga near Barauni industrial area in pollution and biomonitoring of Indian Rivers. Ed. R.K. Trivedy, ABD Publishers, Jaipur, pp: 194-198.

18. Meitei, Shubhchandra, Patil, N., and Bhosle, P.M., (2004), Physicochemical analysis of Purna River for potability. J. Aqua. Biol. 19(1):102-105.

19. Mahananda, M.R., Mohanty, B.P., and N.R. Behera, N.R., (2010), Physicochemical analysis of surface and ground water of Bargarh district, Orissa, India, IJRRAS, vol.2.

20. Purushottam ,Trivedi, A., Singh, A., Srivastava, V. P., Sharma, C. P., Pandey, L. P., Srivastava and Sarika Malik, (2016),An Assessment of Water Quality of Gomati River Particular Relevant To Physicochemical Characteristics, Pesticide And Heavy Metal Journal of Engineering Research and Application, Vol. 6, Issue 9 , pp.66-75.

21. Pramod Kumar, Pandey Anupama and Upadhyay Hem Chandra, (2014),Seasonal variation in physicochemical properties of Kali River in Pithoragargh Uttarakhand, India,Journal of Environmental Research And Development Vol. 8 No. 3A. 
22. Preetysingh, (2014), Studies on seasonal variation in physicochemical parameters of the River Gomti, Uttar Pradesh, India, International Journal of Advanced Research, vol.2, 82-86.

23. Patil, P.R., Manohar R. Patil, V.S., Shrivastava, (2015),Study of the Physicochemical Characteristics of Water Samples and Statistical Analysis of Collected Results of Some Rivers ofMaharashtra, International Journal of Modern Sciences and Technology,Vol. 2, Issue 10, pp.19-27.

24. Radha Krishnan R., Dharmaraj, K., and RanjithaKumari, B. D., (2007), A comparative study on the physicochemical and bacterial analysis of drinking, borewell and sewage water in the three different places of Sivakasi, Journal of Environmental Biology, 28(1), 105-108.

25. Roy, Y., and Kumar, R. A., (2002), A study of water quality of the Rivers of Ranchi district, Ind. J. Environ. Protec, 21(5), 398-402.

26. Srivastava, S., Srivastava, A., Negi, M.P.S., and Tandon, P.K., (2011), Evaluation of effect of drains on water quality of River Gomti in Lucknow city using multivariate statistical techniques, Int. J. Env. Sci., 2:1.

27. Semwal, N., and Akolkar, P., (2006), Water quality assessment of sacred Himalayan Rivers of Uttaranchal. Current Science 91(4):486-496.

28. Singh Chhatrapal Singh, Jay Shankar Kumar, Vikas Chandra Ram and Kumar Neeraj, (2013), Screening out of coliform bacteria from different location of Gomti River, Lucknow. African journalof microbiological research 7(29), 3762-3771.

29. Tebutt, T. H. Y., (1983), Principles of Quality Control. Pergamon, England 235.

30. Tabrej Ahmed, Paul Newton, Shukla K., Sharma A.K.,(2010), Water quality assessment of River Gomti at Lucknow U.P. India. Pollution due to industrial and domestic wastes. Aquacult vol.11 (1), 39-46.

31. West, L., (2006) World Water Day: A Billion People Worldwide Lack Safe Drinking Water, 324-330.

32. World Health Organization (1996), Guidelines for drinking water quality, Volume 2 Recommendations, 2 Edition Geneva.

33. World Health Organization (WHO), (2008), Guideline for Drinking Water Quality: Vol.1, Recommendation $2^{\text {nd }}$ Edition, Geneva.

34. Zeb Bibi Saima, Malik Amir Haider, Waseem Amir and Mahmood Qaisar, (2011), Water quality assessment of Siran River, Pakistan. Int. Journal ofphysical sciences 6(34):7789-7798. 